\title{
THE WAYYIQTOL AS 'PLUPERFECT': WHEN AND WHY
}

C. John Collins

\section{Summary}

This article examines the possibility that the Hebrew wayyiqtol verb form itself, without a previous perfect, may denote what in Western languages would be expressed by a pluperfect tense, and attempts to articulate how we might discern it in a given passage, and the communicative effect of such a usage. The article concludes that there is an unmarked pluperfect usage of the wayyiqtol verb form; and that it may be detected when one of three conditions is met. Application of these results demonstrates that this usage is not present in 1 Samuel 14:24, while it is present in Genesis 2:19.

\section{Introduction}

There is no need to defend the statement of Gesenius that in Classical Hebrew narrative the wayyiqtol verb form (commonly called 'the waw consecutive with "imperfect"') 'serves to express actions, events, or states, which are to be regarded as the temporal or logical sequel of actions, events, or states mentioned immediately before. ${ }^{\prime}$ More recently, practitioners of textlinguistics have referred to the wayyiqtol verb form as 'the backbone or storyline tense of Biblical Hebrew narrative discourse.'2 In general, orderly narrative involves a story in the past tense, about discrete and basically sequential events. ${ }^{3}$

1E. Kautzsch, Gesenius' Hebrew Grammar (trans. A.E. Cowley; Oxford: Clarendon, 1910) §111a.

${ }^{2}$ R.E. Longacre, 'Discourse Perspective on the Hebrew Verb: Affirmation and Restatement', in W. Bodine (ed.), Linguistics and Biblical Hebrew (Winona Lake: Eisenbrauns, 1992) 177-189, p. 178.

${ }^{3}$ Within a paragraph or episode, we have what T. Givón, Topic Continuity in Discourse (Philadelphia: Benjamins, 1983) 8, calls 'action 
In Biblical Hebrew, the wayyiqtol verb form is grammatically marked as conveying this information. 4

There is also little need to discuss the proposition that the normal way to express a pluperfect idea (also called a 'flashback'5) in Classical Hebrew narrative is by the use of the perfect verb form (also called the qatal form), commonly introduced in a narrative with a subordinating conjunction such as 'ăšer or kî, or with some sentence element preposed to the verb. This verb form in narrative is grammatically marked for off-the-main-storyline events. It may introduce an imbedded storyline of time prior to the main storyline, whose backbone sequence will be conveyed by wayyiqtol forms.

Difficulties arise when it appears that the wayyiqtol verb form is used to denote an event prior to the previous verb, i.e., as what in Western languages would be expressed by a pluperfect verb form. The purpose of this paper is to examine claims that such a usage existed in Classical Hebrew; and if it did, to articulate if possible the criteria by which we might discern it in a given passage, and the communicative effect of such a usage. ${ }^{6}$

continuity': 'actions are given primarily in the natural sequential order in which they actually occurred and most commonly there is small if any temporal gap... between one action and the next' (cited in S. Levinsohn, Discourse Features of New Testament Greek [Dallas: Summer Institute of Linguistics, 1992] 14).

${ }^{4}$ Of course we must add nuances to this statement for a full description of Hebrew narrative, as does, e.g., R. Buth: 'various degrees of partial semantic and temporal overlap with a preceding sentence are possible, up to and including a hendiadys like "answered and said"" ('Methodological Collision between Source Criticism and Discourse Analysis: The Problem of "Unmarked Temporal Overlay" and the Pluperfect/non-Sequential wayyiqtol', paper read to the Seminar on Discourse Linguistics and Biblical Hebrew [sponsored by Summer Institute of Linguistics], Dallas, Texas, May 31-June 11, 1993, 1. [This paper is marked as having also been read at SBL, 1991, in absentia, and is slated for publication in R. Bergen (ed.), Collected Papers on Discourse Linguistics and Biblical Hebrew [Dallas: SIL, forthcoming.]).

${ }^{5}$ Longacre, ibid.

${ }^{6}$ Note that these concerns make this approach a broadly text-linguistic one, as described in E. Talstra, 'Text Grammar and Hebrew Bible. I: Elements of a Theory', Bibliotheca Orientalis 35 (1978) 169-174, p. 169. 
The procedure will be as follows: first, I will survey the views of some classical grammarians (Gesenius, Driver, Davidson, Joüon, Waltke-O'Connor ${ }^{7}$; then I will look at the two major studies of this topic (Martin, Baker), neither of which is from a textlinguistic point of view; then I will discuss the recent work of Buth, which makes explicit use of textlinguistic ideas, but is carried out on a much smaller sample than that of Baker. ${ }^{8}$ Buth suggests answers to the questions posed above, and I will examine his answers in light of the larger data base. Finally, I will address some controverted texts (1 Sa. 14:24; Gn. 2:19) to see if this study can yield exegetical results.

\section{Survey of Classical Grammarians}

The grammars of Gesenius and Joüon do not allow for the possibility of a wayyiqtol denoting a pluperfect event, except when it is consequent on a perfect verb form with pluperfect meaning. ${ }^{9}$ Davidson has no independent discussion of the matter: he defers to that in S.R. Driver. ${ }^{10}$

Note further that our data base is the narrative of Genesis through Kings.

7In view of Waltke-O'Connor's rejection of text-linguistic methodology (B.K. Waltke and M. O'Connor, An Introduction to Biblical Hebrew Syntax ${ }^{2}$ [Winona Lake: Eisenbrauns, 1990] 55: 'We have resisted the strong claims of discourse grammarians'), I group them with the 'classical grammarians'. Unlike some in the text-linguistic arena, however, I do not use this category name pejoratively. Talstra (e.g., 'Text grammar I', 170) mentions more than once that text-linguistic discussions of Hebrew would have benefited from more interaction with earlier discussions.

${ }^{8}$ Buth apparently did not use the work of Baker for his study.

${ }^{9}$ See, for example, Gesenius-Kautsch-Cowley §111n-x; P. Joüon, Grammaire de l'hébreu biblique (Rome: Institut Biblique Pontifical, 1923) §118. Note that A. Niccacci, writing from within a text-linguistic perspective, endorses this, The Syntax of the Verb in Classical Hebrew Prose (JSOT Sup 86, Sheffield: Sheffield Academic Press, 1990 [ET of 1986 Italian edition]) $\$ 40$.

${ }^{10}$ A.B. Davidson, Hebrew Syntax ${ }^{3}$ (Edinburgh: T \& T Clark, 1901) $\S 48$ remark 2; Joüon §118d, note 2 also defers to Driver (Muraoka's English 
The most comprehensive of the classical treatments of this subject is that of S.R. Driver in his work on the Hebrew tenses. ${ }^{11}$ After describing the normal use of the wayyiqtol to express chronological sequence (\$§73-74), he noted that some cases 'occur in which no temporal relation is implied at all, and association in thought is the principle guiding the writer rather than association in time' (\$76). Thus he allowed for an 'epexegetical' use of the wayyiqtol verb form (i.e., a comment on the preceding narrative as a whole). ${ }^{12} \mathrm{He}$ then in a long Observation appended to this section, dealt with the 'moot and delicate question how far the [wayyiqtol] denotes a pluperfect. ...[C]an it instead of conducting us as usual to a succeeding act, lead us back to one which is chronologically anterior?'13 After pointing out that the usual way to denote a pluperfect is by means of the perfect verb form, he examined in detail those passages in which native Jewish grammarians, 14 the translators of the $\mathrm{AV}$, and some of his contemporary scholars ${ }^{15}$ had alleged a pluperfect significance to the wayyiqtol form. ${ }^{16}$ His overall conclusion:

In those [wayyiqtol forms] occuring at the beginning of a narrative, or paragraph, there are, as we have seen, reasons for presuming that the chronological principle is in abeyance, and that it is not the intention of the author, or compiler, to

translation maintains this deference: $\mathrm{P}$. Joüon and T. Muraoka, $A$ Grammar of Biblical Hebrew [Rome: Pontifical Biblical Institute, 1993]). 11S.R. Driver, A Treatise on the Use of the Tenses in Hebrew ${ }^{3}$ (Oxford: Clarendon, 1892).

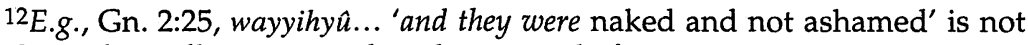
chronologically sequential to the verses before it.

${ }^{13}$ Tenses, 84-89.

${ }^{14}$ Including Ibn Ezra, Kimchi, Abulwalid, Rashi.

${ }^{15}$ Including Keil, Kalisch, Delitzsch, Hitzig, Wright.

${ }^{16} \mathrm{He}$ considered Gn. 2:2, 19; 12:1; 26:18; Ex. 4:19; 11:1; 18:2; 32:39; 33:5; Lv. 9:22; Judg. 1:8; 2:6; 1 Sa. 14:24; 17:13; 23:6; 2 Sa. 5:8; 1 Ki. 7:13ff; 9:14; 13:12;

2 Ki. 20:8; Is. 8:3; 37:5; 39:1; Je. 39:11; Jon. 2:3 [2:4]; Zc. 7:2; Ps. 78:23; Jb. 2:11; Dn. 1:9; Ne. 2:9 (although not in this order). He also labelled a few passages, referred to chiefly by Jewish authorities, as 'inconclusive': Gn. 2:8 (Ibn Ezra); 26:18 (Rashi); Ex. 14:21; 16:20 (both Kimchi); Nu. 1:48 (AV); 1 Sa. 17:21 (AV); Jon. 1:17 [2:1] (AV, see also 4:6, 7); Jb. 14:10 (Tenses, 87, n.3). 
express the precise temporal relation with the occurrence last described. Some of these apparent instances have arisen, doubtless, from the manner in which the Hebrew historical books are evidently constructed, distinct sections, often written by different hands, being joined together without regard to formal unity. ${ }^{17}$...I find it difficult to believe that in the midst of a continuous piece of narrative, such as Gen. 2,19, or even Ex. 11,1, it is legitimate to abandon the normal and natural sense of [the wayyiqtol form] in favour of one which, at best, rests upon precarious and unsatisfactory instances, and which, had it been designed by the author, could have been easily and unambiguously expressed by a slight change of order.

Driver was able to claim the agreement of prominent Hebraists of his day, 18 and his argument has had a wide influence. 19

The important grammar of Waltke and O'Connor, however, disagrees with Driver's conclusions. ${ }^{20}$ They refer to the investigations of Martin and Baker (see below), and fault Driver for inconsistency: after all, 'he allows for the epexegetical use of [the wayyiqtol form], which may entail a pluperfect situation.' They provide three examples that seem clearly to require a pluperfect sense for the wayyiqtol form, and mention David Kimchi as having already pointed out this use. ${ }^{21}$

17In some cases (e.g., Is. 38:21-22) he explained the apparent pluperfect by a supposition of textual misplacement (p. 87).

${ }_{18}$ Such as Böttcher, Pusey, Quarry, and Dillmann.

${ }^{19} \mathrm{As}$ will be seen below in the discussion of $\mathrm{Gn}$. 2:19.

20See Syntax, 551-2 (\$33.2.2) on the epexegetical use of the wayyiqtol form; ibid., 552-3 (\$33.2.3) on the pluperfect use. Even though these authors reject a discourse-oriented framework, all of their examples are from narrative and are therefore useful here.

${ }^{21} \mathrm{Nu}$. 1:47-49; Ex. 4:11-12, 18-19; $1 \mathrm{Ki} .13: 12$. Note that each of these appears in Driver's list of passages: he considered the first 'inconclusive' (Tenses, 87, n. 3); he explained the second two as perhaps referring to a distinct occasion (p. 86); and the last he treated as epexegetical (p. 83: 'the entire buildings having been described, the part taken in their erection by Hiram is mentioned separately'). Note further that Driver was aware of, and attempted to refute, Kimchi's claim for this use of the wayyiqtol verb form. 
Driver and Waltke-O'Connor looked at the same evidence and arrived at different answers. The discussion in Waltke-O'Connor is too brief to serve as a refutation of Driver; we turn, therefore, to the studies of Martin and Baker to which they refer.

\section{The Work of W.J. Martin and D.W. Baker}

In 1969 W.J. Martin published a paper on 'dischronologized' narrative in the Old Testament. ${ }^{22} \mathrm{He}$ was referring to places in narratives in which, for example, the effect is mentioned before the cause or the later before the earlier (thus disrupting the 'normal' flow of a narrative). He claimed to have found this feature in several OT and NT passages, ${ }^{23}$ as well as some Egyptian and Assyrian. He speculates on the possible motivations behind such a usage: a concession to memory; arrangement of events by geographical (or logical) order instead of chronological succession; arrangement according to relative importance.

One of the greatest gaps in Martin's article is the fact that he does not distinguish between verb forms. The question is not whether Hebrew narrative can express a pluperfect idea as such; rather, the issue is the verb forms for doing so intelligibly. Several of his examples do in fact use the wayyiqtol verb form, but Martin does not call attention to this fact.

Martin's student D.W. Baker has made up this lack, however; in a Regent College Master's thesis supervised by Martin he distinguished three categories of pluperfect in Hebrew narrative (Genesis through Kings): that expressed by a perfect verb form; that expressed by a wayyiqtol verb form consequent on a perfect (= imbedded storyline); and that expressed by a wayyiqtol form without previous signals. I will attend to his third category, in which he found enough

22W.J. Martin, "'Dischronologized" narrative in the Old Testament', Congress Volume, Rome 1968: VTS 17 (1969) 179-186.

${ }^{23} \mathrm{His}$ Hebrew passages are: Jos. 2:15-16; 2 Sa. 4:4ff; 12:26-29; 1 Ki. 1:5; 2:7ff; 9:10-14; 11:14-22; 18:1-7; 2 Ki. 24:7. 
examples to establish that this is indeed a possibility in Biblical Hebrew (contrary to Driver's views). ${ }^{24}$

Consider, for example, 1 Kings 21:8-9:

And she [Jezebel] wrote (wattiktöb) letters in the name of Ahab and she sealed them (wattahtom) with his seal and she sent (wattislah) letters to the elders and to the nobles who were in his city, who sat with Naboth, (9) and she wrote (wattiktöb) in the letters, saying...

The verbs in v. 8 are all wayyiqtol forms, as is the verb that begins v. 9. This verb repeats the first verb of $v$. 8 , and thus is prior to the remaining verbs of v. 8 .

A similar phenomenon appears in 2 Kings 7:18-19:

(18) And it happened (wayěhî) as the man of God was speaking to the king... and the officer answered (wayyacan) the man of God and said (wayy $\bar{o}^{\prime} m a r$ )... and [the man of God] said (wayyō'mer)...

These verbs are referring back to actions that took place in vv. 1-2 of the chapter-after the narrator has told us what happened after vv. 1-2. The link to vv. 1-2 is provided by the explicit repetition which serves as a back-reference (anaphora).

Another example is Joshua 18:8, where men are to write a description of the land:

and the men got up (wayyāqūmû) and they went (wayyēe $\bar{e} k \bar{u})$, and Joshua commanded (wayessaw) the men going to write (about) the land...

${ }^{24}$ David W. Baker, The Consecutive non-Perfective in the Historical Books of the Hebrew Old Testament (Genesis-Kings) (unpublished M.C.S. thesis; Regent College, Vancouver, 1973). Though I would analyse many of the passages Baker cites differently from him, I am indebted to this helpful survey. A detailed interaction with Baker's (and others') work will be supplied on request from the author: C. John Collins, Covenant Theological Seminary, 12330 Conway Road, St. Louis, MO 63141, USA. 
It would appear that by saying wayyele $\bar{k} \bar{u}$ the author anticipated their leaving; certainly Joshua had to command them before they actually had left (the effect is almost as if the narrator got ahead of himself and had to double back to record Joshua's instructions).

A clear example comes from 1 Kings 11:14-15:

(14) And the Lord raised up (wayyāqem) an opponent for Solomon, Hadad the Edomite (he was from the seed of the king in Edom). (15) And it happened (wayěhî) when David was with Edom, when Joab went up... and he smote (wayyak)...

The 'raising up' in v. 14 is intelligible as being subsequent to God's threat to Solomon in vv. 9-13; but the temporal expression with the wayyiqtol form wayeh î in v. 15 clearly points back to an earlier time-earlier by a whole generation; and vv. $14 \mathrm{~b}-22$ form an imbedded storyline that is explanatory of (and prior to) v. 14.25

\section{The Study of Buth}

The recent paper of $R$. Buth is from an explicitly textlinguistic point of view. ${ }^{26} \mathrm{He}$ refers to the phenomenon under discussion as 'unmarked temporal overlay' (the usual pluperfect arrangement with the qatal verb form he calls 'marked temporal overlay'): 'the story makes a temporal retreat, it "overlays" a time segment that has already been covered.' He illustrates this unmarked overlay from Judges and from the Moabite Stone.

For example, he draws on an article by E.J. Revell dealing with the battle against Benjamin in Judges 20:29-48.27 Revell shows that 'where the narrative of the first chain of

25It would be possible to argue theologically that the 'raising up' of v. 14 is actually the initiating action of this imbedded storyline; but that would then make the verb wayyäqem the wayyiqtol pluperfect.

26'Methodological collision', 1 .

27E.J. Revell, 'The Battle with Benjamin (Judges xx 29-38) and Hebrew Narrative Techniques', VT 35 (1985) 417-433. 
events must be resumed after the second has been treated, the reader is often returned to the point in the narrative at which the treatment of the second chain began, by means of the repetition of a statement made at that point.'28 Revell documents this literary feature in Judges (using the wayyiqtol verb form: Judg. 11:29, 32; 14:16, 17) and goes on to discuss it in the battle narrative of Judges 20.29 Revell's analysis is quite detailed and one simple example will suffice here. In v. 32a the men of Benjamin say of Israel 'they are beaten (niggāpîm) before us as at first'; we then have an account of the Israelite ambush and defeat of Benjamin (vss. 32b-35). In v. 36 we return to the point of time of 32a: 'and the sons of Benjamin saw (wayyir' $\hat{u})$ that they [Israel] were beaten (niggāpî) and the men of Israel gave place to Benjamin because they trusted the ambush...' Here the repetition is niggapph in v. 36 which corresponds to niggäpim in v. 32, and this is enough to signal the back reference in time. ${ }^{30}$

Buth then treats Judges 11:1:

And Jephthah the Gileadite was a mighty man of valor, and he was the son of a prostitute; and Gilead begat (wayyoled) Jephthah.

The mention of Jephthah's father 'obviously introduces a prior event... Knowledge of the real world... prevents any misunderstanding and guarantees that a non-sequential relationship is understood between the sentences.' 31

${ }^{28}$ Revell, 426, citing S. Talmon, 'The Presentation of Synchroneity and Simultaneity in the Biblical Narrative', Scripta Hierosolymitana 27 (1978) 9-26. Of Baker's examples discussed in section III above, $1 \mathrm{Ki} .21: 9$; $2 \mathrm{Ki}$. 7:18-19; and $2 \mathrm{Sa}$. 13:34 are of this sort.

${ }^{29}$ Revell, following Talmon, notes that 1 Sa. 29:1, recapitulating 28:1, is another example of a wayyiqtol verb form pluperfect.

30Note that Revell's paper has as its 'primary purpose... to show that Judg. xx 29-48 can be understood as a logical and cohesive account of a battle, presented by methods typical of other stories in the book' (417), and that his work was explicitly 'directed against the common view that the passage was incompetently composed [from separate sources]' $(417$, n.1).

31'Methodological Collision', 6. 
Similar to this is Isaiah 39:1, where the order of narration is: Merodach Baladan sent letters and a gift to Hezekiah, and he heard (wayyišmac) that he had been sick and recovered. As Buth puts it, 'Because we understand sympathy, the most appropriate understanding of the passage is that the news of Hezekiah's sickness and recovery prompted the gifts.' 32

Buth also gives an example from the Moabite Stone, ${ }^{33}$ which uses the wayyiqtol verb form much as does Hebrew. At the end of line 4 we pick up the narrative about Omri, king of Israel: 34

(5) And he oppressed (wy`nw) Moab many days, for Chemosh was angry with his land. (6) And his son succeeded him (wyhlph), and he too said (wy'mr), 'I will oppress Moab.' In my days he said thus. (7) And I looked ( $\left.w^{2} r^{\prime}\right)$ [victoriously] on him and on his house, and Israel perished utterly forever. And Omri had taken possession of (wyř ' $m r y$ ) the land of Medebah, and he dwelt in it...

Towards the end of line 7 we find a wayyiqtol verb form wyrš, 'and he took possession' used to express a previous event. Buth refutes those who would interpret this verb form differently, either as a weqatal (perfect consecutive) or as an infinitive: 35

There is no motivation for such structures. The verb is not habitual (the normal meaning of veQatal in narrative) and it is not continuing a description as normal Qatol infinitive. Rather than posit in Moabite a unique function, otherwise unattested for veQatal in Hebrew, it is certainly better to group this Moabite example with a parallel Hebrew phenomenon.

32'Methodological Collision', 9.

${ }^{33}$ This has the advantage that one cannot easily speak of poorly edited sources, or of damage in textual transmission.

${ }^{34}$ Text from J.C.L. Gibson, Syrian Semitic Inscriptions, Vol. I (Oxford: OUP, 1971) 74ff, and translation here based on Gibson's.

${ }^{35}$ Compare Driver, Notes on the Hebrew Text and the Topography of the Books of Samuel (Oxford: Clarendon, 1912) lxxxix-xc; Gibson, Syrian Semitic Inscriptions I, 78. 
Buth points out that the 'mention of Omri [in line 7] returns the narrative to a generation before King Mesha and before the time when Moab subdued Israel.'36

Buth is then able to posit the conditions in which the phenomenon of 'unmarked overlay' occurs and how we can recognise it. He finds 'two limited environments for unmarked temporal overlay':37

(1) 'Some lexical redundancy or reference specifically points back to a previous event.' This anaphoric reference would explain, e.g., the examples in Judges 20:36 and the Moabite Stone, line 7.

(2) 'From common cultural experience an event can be interpreted as giving a reason or otherwise commenting on the events immediately preceding.' This would explain Judges $11: 1$.

Buth then explores the possible communicative effects of this structure, and applies his criteria to Genesis 2:8, 19 (arguing that they are not instances of this phenomenon); but discussion of these points will be reserved for later in this paper.

\section{Criteria for the Unmarked wayyiqtol Pluperfect}

The aim of this section is to build on Buth's analysis, applying it to the larger data set found in Baker. ${ }^{38}$ In considering Baker's evidence, the first thing that becomes clear is that Buth's criteria are too restrictive to cover all of the data. It would be better to say that the wayyiqtol may express pluperfect time when one or more of the following three conditions are met:

(1) Some anaphoric reference explicitly points back to a previous event. This is Buth's first condition, and in addition to

36'Methodological Collision', 8.

37'Methodological Collision', 9.

${ }^{38}$ Note that Buth offers a number of verses in Judges where the consecutive tense is used with 'temporal irregularities'. Some of these are better classed as 'recapitulative': Judg. 9:56; 17:12; 21:6; while in some others it is not possible to tell just where he found the temporal irregularity: e.g., Judg. 2:1, 14, 21; 3:4, 10. For more of his convincing examples see below. 
the verses explained by Buth, this would explain 1 Kings 21:89; 2 Kings 7:18-19; and possibly 2 Samuel 13:34 as discussed below. 39

(2) The logic of the referent described requires that an event presented by a wayyiqtol verb form actually took place prior to the event presented by a previous verb. 40 This would explain. e.g., Joshua 18:8, as well as those passages explained in Buth's second condition. 41

(3) The verb begins a section or paragraph. This was the sole instance allowed by Driver, in which he agreed that 'the chronological principle' of the wayyiqtol might be 'in abeyance'. Note that this also helps explain 2 Samuel 13:34 (discussed below). 42

${ }^{39}$ Additional examples from Baker: 1 Sa. 14:6 (looks back to v. 1); 2 Sa. 4:7 (restates v. 6, perhaps as an action peak); from Buth: Judg. 2:20 (back to v. 14); $3: 7$ (back to 2:11); 7:22 (back to v. 20); 17:4 (restates v. 3); $18: 20$ (back to vv. 17-18, but notice different subjects of verb läqah); 18:31 (wayyāsîma is a restatement of wayyāqîma in v. 30 ).

${ }^{40}$ This statement of the condition is wider than Buth's, which is too narrowly cast to cover all the data. Buth would restrict this to 'common cultural experience', but how does that explain Is. 38:22 (compare parallel in $2 \mathrm{Ki}$. $20: 8 \mathrm{ff}$.), $1 \mathrm{Ki}$. 11:15, or Jos. 18:8? Baker argues that wayyiben...wayyiqra ${ }^{3}$ in $\mathrm{Gn}$. 35:7 (the building of an altar and the naming of the place) refers to the action of 28:18-19, and hence should be taken as pluperfect/epexegetical. If this is so, then the literary context can establish 'the logic of the referent' (much as in $1 \mathrm{Ki} .11: 15$, where wayeh $\hat{\imath}$ + time expression [or wayyäqem in v. 14, see discussion in section III above] refers to an event prior to its preceding context). This appeal to 'the logic of the referent' is only an application of 'the reality principle' described in P. Cotterell and M.M.B. Turner, Linguistics and Biblical Interpretation (Downers Grove: IVP, 1989) 264f. (with references to linguists).

${ }^{41}$ Additional examples from Baker: Gn. 29:24; 35:6-7 (28:18 gives the occurrence of events); Ex. 2:10; Jos. 2:16; 13:24, 29 (also satisfy criterion 3 since they begin paragraphs); 18:8; 1 Sa. 26:4; from Buth: Judg. 1:5, 8, 10 (explanations of the summary statement in v. 4); 3:16 (before last verb of $\mathrm{v} .15)$.

42Additional examples from Baker: Gn. 19:29; 2 Sa. 12:26 (This verse satisfies criterion 1 also); from other sources: Judg. 2:6 (so Driver, Tenses, 86); Jon. 1:17 [2:1] (1:16 took us to the sailors' return to shore; now we return to Jonah; also fits criterion 1); 2:3 [2:4] (but of course this is poetic). 


\section{Communicative Effect of Unmarked Temporal Overlay}

Several of the authors cited above speculate on the effect of using the unmarked form to express a pluperfect idea, notably Martin and Buth. Martin, for example, contended:

'The major consideration with any writer of literary talent would be to present his material so organized as to stimulate attention and to communicate it effectively.' 43

Martin was not specifically dealing with the question of verb forms normally used to describe successive events, being used abnormally to express a 'pluperfect' action, and Buth's speculations are more concrete. Buth says: 44

With regard to communicative effect, in back-to-back sentences where the natural relationship of the events provides the proper understanding one can say that the vayyiqtol clause reports its event as a main-line event. It avoids making any semantic relationship like 'reason' or 'grounds' and it avoids breaking up the structure of the narrative with a structurally marked aside or parenthesis.

In cases where lexical reference or repetition signals a backreference one can again hypothesize that the author is primarily concerned in portraying 'main-line' events with the vayyiqtol structure. The constraint of adding details to a passage without also demoting them off the main line gives rise to this non-sequential use of the vayyiqtol. Thus, for both lexically signalled temporal overlay as well as semantically natural temporal overlay the vayyiqtol structure lifts a clause to the main line without making another relationship prominent.

Buth goes on to speculate about the literary effect of the unmarked overlay in Judges 20:31-48 (discussed in section IV above):45

${ }^{43}{ }^{\prime}$ Dischronologized Narrative', 186.

44'Methodological Collision', 9.

45’Methodological Collision', 11. 
...we can explain the exuberance of unmarked overlay in Judges $20: 31-48$ as a grammatical imitation of the military and even moral confusion that the author attributed to that episode... It was a lawless time and the complications of the unholy, fratricidal battle are highlighted by forcing the audience to untangle the scenes by using the subtle lexical clues of unmarked overlay.

Revell, in the article from which Buth drew, made the more prosaic comment that:

The complexity of the account is undoubtedly due, in part, to the need to present the activities of three different groups participating in the battle, a problem not often presented to the narrator, and difficult to solve within the linear convention of Hebrew narrative. ${ }^{46}$

Perhaps it would be helpful to think about the communication situation between an author and his audience. ${ }^{47}$ As an audience we naturally assume that an author will follow the 'Cooperative Principle' articulated by Grice: 48

(a) maxim of quantity: say neither more nor less information than is required. (b) maxim of quality: say what you have grounds to believe is true. (c) maxim of relation: be relevant. (d) maxims of manner: be perspicuous, specifically (i) avoid obscurity of expression; (ii) avoid ambiguity; (iii) be brief; (iv) be orderly.

If an author violates one of these rules from carelessness he usually produces a literary blemish; however, sometimes a

46'Battle with Benjamin', 432. See also P.E. Satterthwaite, 'Narrative Artistry in the Composition of Judges xx.29ff', VT 42 (1992) 80-89, who explores the narrative artistry of this account within Revell's framework; this interesting paper does not, however, discuss the grammatical issues (on pp. 80-81 he expresses satisfaction with Revell's work).

47Many of the ideas in what follows are influenced by Mary Louise Pratt, Toward a Speech Act Theory of Literary Discourse (Bloomington: Indiana UP, 1977) 100-200.

${ }^{48}$ H.P. Grice, whose theory of the Cooperative Principle is outlined in Pratt, Speech Act Theory, 125-132. 
writer may knowingly fail to fulfill one of the rules, and that can be interesting: it might even suggest that a speech act is being performed that does not necessarily correspond to the surface form of the linguistic expression. 49

From the grammars of Gesenius, Driver, Joüon, and Waltke-O'Connor, as well as from discourse studies such as those of Talstra, Longacre, and Niccacci, it seems fair to conclude that the Hebrew audience assumed that the maxims of manner implied that in narrative an author would use the wayyiqtol verb form so that 'actions are given primarily in the natural sequential order in which they actually occurred and most commonly there is a small if any temporal gap between one action and the next.'50 Successive wayyiqtol verbs should advance the time line. Variations are granted: a given wayyiqtol form may be epexegetical (explanatory), or recapitulative (summing up), or a verb pair may form an idiomatic hendiadys; 51 and that will be clear from the semantics of the verb and the logic of the situation. Some of the pluperfect wayyiqtol examples may be adequately explained within these allowable variations, or within the bounds of accepted style; 52 but others are 'violations' of this 'contract' between author and audience. ${ }^{53}$ When these violations are detectible then we

49Pratt, Speech Act Theory, 158-200.

${ }^{50} \mathrm{~T}$. Givón, cited by Levinsohn, as above in n. 3 .

${ }^{51}$ Such as wayya ${ }^{c}$ an wayyömer, 'and he answered and said'.

${ }^{52} \mathrm{As}$ an example, consider Judg. 1:4, which gives a summary description of Judah's conquests, while vv. 5, 8, 10 fill in successive details of how v. 4 was accomplished, all using wayyiqtol forms. This is probably the best way to understand $1 \mathrm{Ki}$. 11:15 (discussed in section III above); perhaps also $2 \mathrm{Ki}$. 22:3 in relation to v. 2 . This would then be the inverse of the recapitulative wayyiqtol. This bears some relation to what J.T. Willis called 'anticipatory redactional joints' in $Z A W 85$ (1973) 294-314; but Willis does not discuss the question in terms of verb forms.

53It seems better to understand the conventions of the wayyiqtol form in terms of the hearers' side, rather than to follow Davidson's explanation, according to which the form 'may express either what is strictly consequential, or what is merely successive in time, or what is only successive in the mind of the speaker' (Syntax, §47, emphasis added). Davidson is explaining it from the artist's side; but, as C.S. Lewis observed, 'all art is made to face the audience. Nothing can be 
are alerted that something interesting may be in store for us. ${ }^{54}$ Just what the literary effect might be, we must ascertain case by case.

Buth's speculations about the effect of the wholesale 'violations' in Judges 20 serve as an example; in the discussion of Joshua 18:8 in section III above we find another. A number of Baker's examples, which have been commonly explained as due to textual corruption, might better be considered in this light.

For example, consider Genesis 29:23-25:

(23) And it came about (wayěhî) in the evening, and he [Laban] took (wayyiqqah) Leah his daughter and brought (wayyāb $\bar{e}^{\prime}$ ) her to him [Jacob] and he [Jacob] went (wayyābo $\bar{o}^{\prime}$ ) to her. (24) And Laban gave (wayyittēn) to her Zilpah his handmaid, to Leah his daughter (as) a handmaid. (25) And it came about (wayĕhî) in the morning, and look! It was Leah! (wěhinnēh $\left.h \hat{\imath}^{\prime} l \bar{e}^{\prime} \hat{a}\right)$ And he [Jacob] said (wayyō'mer) to Laban, 'What is this you have done to me?'

It makes sense to assume with Baker that Laban gave Zilpah to Leah some other time than between Jacob's entry to consummate the marriage and his waking up the next morning, most likely prior to it. 55 Verse 24 in its present position interrupts the flow of vv. $23-25.56$ And the reason is

left exposed, however useful to the performer, which is not delightful or at least tolerable to them... We must therefore consider what these [literary devices] do for the hearers, not what they do for the poet' ( $A$ Preface to Paradise Lost [Oxford: OUP, 1942] 19).

${ }^{54}$ Of course we are not here dealing with intentional, undetectible violations, which could count as being deceptive.

55If afterwards, then the problem does not go away: the discussion then becomes about wayeht $(\mathrm{v}$. 25) instead of about wayyittenn. One or the other verb is out of chronological sequence.

${ }^{56}$ This has led some commentators to see the verse as an interposition, e.g., C. Westermann, Genesis 12-36 (Minneapolis: Augsburg, 1985, ET of 1981 German): 'v. 25a produces its effect only when it follows immediately on v. 23... The same holds for v. 29.' But see E.A. Speiser, Genesis (Anchor Bible; Garden City: Doubleday, 1964), who argues for the unity of the account. The question becomes, have we a clumsy interpolator or a careful author/editor? The grammar and literary effect argue the latter. 
plain: everything is being told so blandly, and the reader/hearer shares the surprise experienced by Jacob in v. 25 (note the use of the exclamation wěhinnēh hî̀' lè' $\hat{a}$, 'and look! It's Leah!'). The unusual use of the wayyiqtol verb form puts us off guard, as it were. 57

Recorded in 2 Samuel 4:6-7 we find the brutal murder of Ishbosheth:58

(6) And thither they came $\left(b \bar{a}^{3} \hat{u}\right)$, to the middle of the house, carrying wheat; and they struck him (wayyakkühu) [i.e., Ishbosheth] to the belly, and Rechab and Baanah his brother escaped (nimlātâu). (7) And they came (wayyābo $\bar{o}^{\prime} \hat{u}$ ) to the house and he [Ishbosheth] was lying on his bed in his bedroom, and they struck him (wayyakkūhûu) and killed him (wayĕmîtūhh and removed (wayyāsîrû) his head and they took (wayyiqqěhâu) his head and went (wayyelěeku) by way of the Arabah all night.

If the text is taken as it stands, 59 v. 7 seems to be a restatement of $v$. 6. Surely this has the effect of slowing down the advance of the action; v. 7 would then be like a slow-motion replay of the gruesome scene.60

A final example from Baker's list is 2 Samuel 13:34. In vv. 23-29 we read the description of Absalom's successful plot

${ }^{57}$ Note how in vv. 28-30, the order of narration is more 'natural': Laban gave Rachel to Jacob; Laban gave Bilhah to Rachel for a handmaid; Jacob went to Rachel to consummate the marriage. Here there is no element of surprise. See also M. Sternberg, The Poetics of Biblical Narrative (Bloomington: Indiana UP, 1985) 243.

${ }^{58}$ The judgment that this murder is 'brutal' is given by David (and implicitly by the narrator), vv. 9-12.

${ }^{59}$ Driver, Notes on the Hebrew text of Samuel, followed Wellhausen in recommending emendation on the basis of the way v. 6 'anticipate[s] prematurely' v. 7, with some appeal to LXX. He does not consider whether this anticipation is intentional and artistically motivated. R.P. Gordon, I \& II Samuel (Grand Rapids: Zondervan, 1986) emends the text, without arguing for his emendation; P.K. McCarter, 2 Samuel (Anchor Bible; Garden City: Doubleday, 1984), calls MT a 'redundant anticipation of subsequent material'; A.A. Anderson, 2 Samuel (Word Biblical Commentary, Waco: Word, 1989), supports MT as intelligible. ${ }^{60}$ Somewhat similar would be Judg. 17:4, which covers the same ground as v. 3 (and uses wayyiqtol verbs); 18:18, which restates v. 17 (this time introducing the restatement with a more natural qatal verb). 
to kill Amnon, which ends in v. 29 with all the sons of David fleeing (wayyānūsu-presumably that includes Absalom). Then vv. 30-33 relate the report of the murder coming to David; this of course takes place after v. 29. Verse 34, however, is a flashback to v. 29: 'And Absalom fled (wayyibrah); and the lad who kept watch lifted up (wayyiśs $\bar{a}^{2}$ ) his eyes and saw (wayyar ${ }^{\prime}$...'; there follows the narration of the return of the survivors of Absalom's plot.61 Note that v. 34, though it opens with a wayyiqtol verb form, takes us back to v. 29; note also that vss. 37 and 38 have the 'normal' pluperfect construction, wĕ’abšalôm bärah. 'Now as for Absalom-he had fled.' 62 The anaphoric reference in v. 34 is a way of picking up one thread of a plot, after another has been followed, without introducing anything like contrast or prominence.

A difficult text can be explained in one of several ways: ineptitude on the part of the original author; poor editing into the final form; textual corruption; or a literary device we do not yet understand. When we are able to establish that a given text is grammatical, we will do well to hesitate before recommending emendation (as with 2 Sa. 4:6-7; 13:34); even the appeal to supposed sources (Gn. 29:23-25) and the way they have been edited is precarious, since we do not normally have these sources.

\section{Application of the Criteria to Controverted Passages}

Two passages on which it is interesting to apply the criteria of section V above are 1 Samuel 14:24 and Genesis 2:19.

\footnotetext{
${ }^{61}$ Driver, Samuel, considered the opening words of v. 34 'an awkward anticipation of $37 a^{\prime}$, but did not say why the words are awkward. He listed a number of suggested emendations, but did not commit himself. McCarter, 2 Samuel, concedes that 'all witnesses read with $\mathrm{MT}^{\prime}$; but continues 'the notice anticipates v. 38 and is out of place at this point'. Surely this is subjective and cannot be decisive, in view of the grammaticality of the verb form. Both Gordon, I \& II Samuel, and Anderson, 2 Samuel, keep MT as is.

62The use of the fronted subject 'Absalom', attached to the waw, is probably for contrast between Absalom and David.
} 


\section{1 Samuel 14:24 63}

This verse begins with a weX qatal construction, followed by a wayyiqtol verb:

and the men of Israel were distressed (wěê̌ yiśr $\bar{a}^{\jmath} \bar{e} l$ niggaś) on that day, and Saul laid an oath (wayyo $\left.\bar{o}^{\top} \bar{e}\right)^{64}$ on the people...

The common translation of this verse takes the wayyiqtol form wayy $\bar{o}^{\prime} \bar{e} l$ as some sort of pluperfect or epexegetical remark: e.g., NIV, 'Now the men of Israel were in distress that day because Saul had bound the people under an oath' (compare RSV). Is this likely in view of the findings of this study? Surely the answer is 'no', as Long has convincingly argued.

The weX qatal construction that begins the verse is the common way to 'flashback' or to express a pluperfect. Long shows that the verb niggas is a back-reference to 13:6, where it also appears, so that "v. 24 should be read as a "flashback" or retrospective description of events which took place just prior to Saul's advance on Michmash.' Long observes that the syntax of v. 24 'suggests that the distress of the men of Israel may have prompted rather than resulted from Saul's oath' (emphasis his), that is, the wayyiqtol normally expresses subsequent action. The back reference of the perfect verb (which is commonly continued by a wayyiqtol chain), and the criteria of section $\mathrm{V}$ above (none of which are met) make Long's position inescapable. ${ }^{65}$

\section{Genesis 2:19}

The creation narrative of Genesis 1:1-2:3 presents the origin of the world in six 'days', which are generally taken to be broadly

${ }^{63}$ This passage is well discussed in V.P. Long, The Reign and Rejection of King Saul: A Case for Literary and Theological Coherence (SBLDS 118; Atlanta: Scholars, 1989) 114-117, to which this treatment is heavily indebted, and which this study supports.

${ }^{64}$ For lexical discussion of a possible double entendre, see Long, Reign and Rejection, 117.

65For an insightful reading of the narrative's intent in view of this syntax, see Long, Reign and Rejection, 116. 
sequential.66 The fifth 'day', Genesis 1:20-23, recounts the creation of the birds; while the sixth 'day', 1:24-31, tells of the creation of land animals, followed by the creation of man. The so-called second creation account, Genesis 2:4-25, has the creation of man (2:7), apparently followed by the formation of the Garden of Eden (2:8-9), and the formation of the animals and birds (2:19). The apparent sequence of Genesis 2 is conveyed by wayyiqtol verb forms, and if these are understood sequentially as is the normal usage, then Genesis 2 seems to be at odds with Genesis 1. This disagreement in order is one of the building blocks of the theory that finds in these chapters evidence of combination from separate sources. This disagreement could be eliminated if, in particular, the wayyiqtol verb that opens 2:19, wayyișer yhwh 'élōhim... ('and the Lord God formed...'), could be taken as a pluperfect: 'he had formed' 67

Driver's treatment of the possibility of the wayyiqtol verb form expressing a pluperfect (section II above) has carried the day in discussions of this verse. Spurrell simply referred to it, and finds evidence that the author of 2:19 'conceived the formation of animals as posterior to that of man.' Skinner said that Driver's discussion rules out the pluperfect interpretation of 2:19: 'such a sense is excluded by grammar, and misses the point of the passage.' 68 Indeed, even commentators who are inclined to reject source divisions accept Driver's grammatical

${ }^{66}$ See C.J. Collins, 'How old is the earth? Anthropomorphic days in Genesis 1.1-2.3' (Presbyterion 20:2 [1994] 109-130).

67The pluperfect wayyiqtol verb interpretation has come from such commentators as C.F. Keil (The Pentateuch [Eerdmans, 1981, reprint of 1875 ET from German], referring to $1 \mathrm{Ki}$. 7:13; Judg. 2:6), F. Delitzsch ( $A$ New Commentary on Genesis, ET [Edinburgh: T. \& T. Clark, 1888], referring to Is. 37:5; Jon. 2:4; Zc. 7:2, and the use of the Arabic conjunction), and H.C. Leupold (Exposition of Genesis [Grand Rapids: Baker, 1980, originally 1942], who says the pluperfect is possible but does not show how).

${ }^{68} \mathrm{G} . J$. Spurrell, Notes on the Text of the Book of Genesis (Oxford: Clarendon, 1896); J. Skinner, A Critical and Exegetical Commentary on Genesis (ICC; Edinburgh: T. \& T. Clark, 1930). C. Westermann, Genesis 1-11 (Minneapolis: Augsburg, 1984 , ET of 1974 German), simply assumes the division and has no discussion of this point; similarly G.J. Wenham, Genesis 1-15 (WBC; Waco: Word, 1987). 
point and try to give a harmonising interpretation, along the lines of Cassuto: he notes that whereas v. 20 speaks of the man naming three classes of animals ('cattle', 'birds', 'beasts of the field'), v. 19 speaks only of the forming of the last two:

Hence it seems that in the passage before us (in the ancient epic poem the position may have been different) we must understand the creation of the beasts and the flying creatures in a similar sense to that of the growing of the trees in v. 9, to wit, that of all the species of beasts and flying creatures that had already been created and had spread over the face of the earth and the firmament of the heavens, the Lord God now formed particular specimens for the purpose of presenting them all before man in the midst of the garden. 69

In general the translations (e.g., AV, RSV, NRSV, NASB, NKJV) follow Driver's reasoning. The NIV alone of major versions has a pluperfect in this verse.

Buth's paper contains the only major study of this issue in this verse from a textlinguistic point of view. He also rejects the pluperfect interpretation: 70

We must ask, do these verses [Gn. 2:8, 19, both of which are pluperfect in the NIV] meet the criteria for unmarked temporal overlay? The answer, simply, is no. The verbs do not repeat lexical material to refer the reader back to some particular event which had already been mentioned [his first criterion]. [For v. 19] no earlier 'forming' is mentioned, though one could claim that animals had been mentioned in chapter one. Even with the animals, however, one does not find a back-reference to which this account in 2:19 can be considered an overlay.

Looking at the question of a natural semantic relationship, we find that verses 8 and 19 are not readily perceivable as reasons or explanations to the immediately preceding sentences. We must read these verses as normal sequential

${ }^{69}$ Cassuto, Genesis, 129; followed by J. Sailhamer, 'Genesis', in volume 2 of F. Gaebelin (ed.), The Expositor's Bible Commentary (Grand Rapids: Zondervan, 1990); apparently also by V.P. Hamilton, Genesis 117 (NICOT; Grand Rapids: Eerdmans, 1990).

70’Methodological Collision', 10-11. 
vav hahippuk verbs. Consequently the NIV translation of Genesis 2 must be rejected from a discourse syntax perspective as a misuse of a poorly defined older syntax.

He labels the NIV as 'harmonistic exegesis' and supposes that here, in view of the textlinguistic principles he has articulated, 'the recognition of different sources... will be the more secure.'

However, several factors argue against Buth's position. First, there is the point that the data base from which he inferred the rules for an unmarked wayyiqtol pluperfect is too small. In particular, the recasting of the second criterion (as above, section V), when 'the logic of the referent described requires that an event presented by a wayyiqtol verb form actually took place prior to the event presented by a previous verb', leads us to ask, what is the logic of the referents in Genesis 2:19? This in turn leads us to the question of whether it is legitimate to harmonise the two accounts of 1:1-2:3 and 2:425 (i.e., taking the second account as describing in more detail the sixth 'day'). Are they not from separate sources?

Since we do not physically have the putative sources, this last question is diminished in relevance. What we do have is evidence that the author or editor of Genesis 1-2 as we have it, intended for us to read them together, namely Genesis 2:4. The chiastic structure of this verse has received comment elsewhere: 71

These are the generations of

a: the heavens

b: and the earth

c: when they were created

$c^{\prime}$ : when ${ }^{72}$ the Lord God made

b': earth

$a^{\prime}$ : and heavens

${ }^{71}$ E.g., Niccacci, Syntax, 200 n. 26; Wenham, Genesis 1-15, ad loc.; S. Kempf, 'The Structure and Function of Gen 2:4b-7', paper read to the Seminar on Discourse Linguistics and Biblical Hebrew, Dallas, Texas, May 31-June 11, 1993, p. 10 (with full bibliography).

${ }^{72}$ For this meaning of běyôm followed by an infinitive construct, see Brown-Driver-Briggs, $A$ Hebrew and English lexicon of the Old Testament (Oxford: Clarendon, 1906) 400a; Joüon, §129p. See Am. 3:14; Ex. 32:34; Lv. 13:14; with a finite verb, see Ps. 102:2 [3]; 138:3; etc. 
Such an elaborate chiasmus is evidence of art, not coincidence. Further, by this means the author has tied the two accounts together: note how the word order 'the heavens and the earth' (a and b), as well as the verb bärä', 'create' (c), point us back to 1:1 (as well as 1:21, 27 for the verb); whereas the change in divine name from 'ĕlōhîm, 'God' (ch. 1) to yhwh 'ĕlöhîm, 'the Lord God' (chs. 2-3) is reflected in the c' element. ${ }^{73}$ It is hard to escape the conclusion that the final editor wanted his readers to read the two accounts as complementary, not contradictory; the traditional approach that sees 2:4-25 as an elaboration of the sixth 'day' is how an audience would co-operate with this intention of the author/editor. ${ }^{74}$

It has been argued above (section $\mathrm{V}$ ) that literary environment ('co-text') can establish the 'logic of the referents', i.e., it can tell us what the author thought was the 'actual' sequence of events. If we take Genesis 1:3-2:3 as conveying the broad-stroke story line, which seems to be the simplest way to read it, we are entitled, by the second criterion of section $\mathrm{V}$, to read wayyiser in 2:19 as a pluperfect. It remains to ask why the author narrated events this way, instead of what Driver correctly considered the easy and unambiguous method of a perfect verb with preposed element (e.g., wyhwh 'élōhîm yāșar). Perhaps the simplest explanation comes from the fact that both accounts are strongly anthropocentric: they see man as the pinnacle of God's creative work, the one for whom the earth and its animals exist. Putting the animals' formation in 2:19 directly after 2:18, where God sets about making a helper suitable for the man, reinforces this point: even though physically the animals were made before man, yet conceptually their creation was in anticipation of their subservience to his governance, and therefore in God's mind the animals were a logical consequence of the making of man. Since Genesis 1 had established the physical order so that the

\footnotetext{
73Perhaps the syntax of 2:17 kî bĕyôm 'ăkolěkä mimmennû, 'for when you eat from it', using beyôm, with infinitive, is also foreshadowed in the c' line.

${ }^{74}$ It is also hard to disagree with Cassuto, that if Gn. 2:19 is in disharmony with $\mathrm{Gn} .1$, the redactor 'must... have noticed so glaring a contradiction.'
} 
audience would not mistake it, the author/editor was free to use this literary device to make this theological point.

There is, therefore, good reason, both from Hebrew grammar and from the structure of the first two chapters of Genesis, to support the pluperfect interpretation in 2:19.75

${ }^{75}$ The NIV's pluperfect in v. 8 is not so easily defended: it is likely that the author wants us to see the planting of the garden as physically subsequent to the formation of the man, since the verse ends with 'ăšer $y \overline{a s s a r}$, 'which he had planted.' The sprouting of v. 9 need only refer to the 'ground' in Eden, and need not contradict 1:9-13 (as Cassuto observed). Of course, our concept of the logic of the situation may suggest that God planted the garden first, in which case the pluperfect is justified. Since cooperation with the text does not require a pluperfect in v. 8 , it is better not to find it there. 